\title{
Assessment of biochemical methods to detect enzymatic depolymerization of polysaccharides
}

\author{
C. Rigouin ${ }^{a, b}$, C. Delbarre ${ }^{a,{ }^{*}}$, C. Sinquin ${ }^{a}$, S. Colliec-Jouault ${ }^{a}$ and M. Dion ${ }^{b}$ \\ a Laboratoire de Biotechnologie et Molécules Marines, Ifremer, rue de l'lle d'Yeu, BP21105, 44311 Nantes, Cedex \\ 3, France \\ b Université de Nantes, Laboratoire de Biocatalyse, UMR-CNRS 6204, Biotechnologie, Biocatalyse, Bioregulation, \\ Faculté des Sciences et des Techniques, 2 rue de la Houssinière, BP 92208 Nantes, F-44322Cedex 3, France \\ *: Corresponding author : C. Delbarre, Tel : +33 0 240374057; fax: +33 0 240374071, email address : \\ Christine.Delbarre.Ladrat@ifremer.fr
}

\begin{abstract}
:
To find biocatalyst allowing depolymerization of new polysaccharides, one needs to get a sensitive and well adapted method to a screening program. This led us to compare biochemical methods of detection of the depolymerization. Currently used methods such as reducing sugars assays, double bond monitoring or molecular weight determination were tested to follow the kinetic of depolymerization with different enzyme / polysaccharide couples. The range of concentrations of assorted enzymes allowed us to identify the most sensitive and appropriate method to detect polysaccharide degradation. Reducing sugars assays are quantitative, sensitive and almost usable with all kind of polysaccharide but some compounds may interfere with them. When polysaccharide is bearing charges, agarose gel electrophoresis, although being a qualitative assay is as sensitive as high performance size exclusion chromatography analysis, easy to handle, quite high-throughput and thus preferred.
\end{abstract}

Keywords: carbohydrate; depolymerization; enzyme; detection 


\section{Introduction}

Polysaccharides are biopolymers widely used in many industrial domains thus acting as thickeners, stabilizers, emulsifying agents in foods, cosmetics, paints, oil recovery...

In recent years, there has been a growing interest in the isolation and identification of new microbial polysaccharides; they offer fascinating applications especially for the pharmaceutical industry as new heparin-like or hyaluronic acid-like therapeutic molecules (Colliec Jouault et al., 2001 ; Colliec-Jouault et al., 2004 ; Zanchetta et al., 2003). The molecular features of glycopolymers are obviously of critical importance for their biological activity ; this includes molecular weight as well as osidic residues nature, osidic linkage type and chemical substituents in the repetitive unit. The polymerization degree of the polysaccharides showed itself very important for the biological activity in the domain of the health (Samama and Desnoyers, 1997 ; Weitz and Hirsh, 1997).

Modification processes resulting in a low molecular weight polysaccharide are at present performed by chemical methods : depolymerization by acid hydrolysis (Guezennec et al., 1998), radical depolymerization (Nardella et al., 1996). However, a chemical depolymerization can entail the loss of a substituent as it was reported for the acid hydrolysis (Shively and Conrad, 1976). The radical depolymerization could engender modifications of osidic cycles (Ofman et al., 1997). Therefore, alternative methods to conventional chemical one are being investigated for lowering molecular weight of polymers. The use of enzymes could allow a better specificity of the reaction as well as a better control of the process with fewer parasite reactions and environmentally friendly conditions.

Degradation of polymers requires specialized enzyme systems. The complexity of the structure of the polysaccharide substrates and the high substrate specificity of enzymes may compel us to find new enzymes for almost every new structure of polysaccharide.

Such enzymes may be searched among commercially available enzymes or have to be found from the environment, usually from a microbial source. Thus, relevant and effective methods for the screening programme are required to find the best biocatalyst. Occasionally, some of these methods may be transposed at an high throughput level and allow to create in-lab a new enzyme with the appropriate activity by directed evolution. Furthermore, these methods can be used for the enzymatic features determination: temperature, $\mathrm{pH}$, optima of activity, substrate affinity, specificity etc... Standardization of activity determinations is also needed.

Measuring an endo-enzyme activity is difficult. Plate detection methods of microorganisms producing carbohydrate depolymerising enzymes have been reviewed by Ruijssenaars and Hartmans (2001). Soluble and insoluble dye-labelled polymeric substrates in liquid assays and plate methods (Gómez Ramírez et al., 2004 ; Pettersson and Eriksson, 2000 ; Ten et al., 2004) as well as complex formation between a dye and the polysaccharide (Wood et al., 1988) have been used. However, not all polysaccharides can be efficiently labelled. Alternatively, viscosity changes of polymer solutions incubated with the enzymes can be monitored (Kühn et al., 2004) but this kind of analysis is rather practised in food industry where polysaccharide quantities are not limited. Moreover, these methods do not provide any information on the molecular weight of the products obtained upon enzyme actions, a parameter which is crucial for uses as therapeutic molecules. Since they seemed not entirely satisfactory for this kind of application we removed them from this study.

Some other fast, sensitive, and reliable techniques have been proposed to estimate the breakdown extent of a polymer. The detection of a decrease of the molecular mass of polymers can be made by biophysical methods such as size exclusion chromatographic analysis (HPSec) or electrophoretic analysis for charged polysaccharide. In that latter case, the migration distance is dependent to the size together with the charge. Electrophoresis may be realized on horizontal agarose gel, suited for high molecular weight polymers, or on vertical polyacrylamide gel intended for oligosaccharides. Stains have to be chosen according to the structure of the molecule : alcian blue, toluidine blue for sulfated polysaccharides, Schiff reagent for polysaccharides presenting vicinal diols. Depending on the polysaccharide molecule, other stains may be used (Campbell et al., 1983; Volpi and Maccari, 2006). Some biochemical commonly used assays for activity are based on the monitoring of the released reducing sugars by either the dinitrosalicylic (DNS) assay (Miller, 1959), or by the hexacyanoferrate assay (Myklestad et al., 1997 ; Park and Johnson, 1949). Double bonds generated by polysaccharide lyases (Sutherland, 1995) may be followed at $232 \mathrm{~nm}$ or assayed with the thiobarbituric acid (Nedjma et al., 2001).

Due to the considerable differences in substrate structure, degree of polymerization, degree of substitution and to the diversity of enzyme sources and activities, there is a need to identify the best adapted method, with the best sensitivity, giving low background and allowing a high throughput 
screening. Until now no really accurate comparisons of those biochemical detection methods have been made in this field.

In this work we have used some of the more current and known sensitive methods to detect and measure carbohydrate depolymerizing enzymes. Reducing sugar assays, double bond monitoring and molecular weight analysis (HPSec, electrophoresis) methods and results are assessed for three commercial endo-enzymes: hyaluronidase, alginate lyase and pectinase as well as one exo-enzyme produced in lab, a pectate lyase.

\section{Materials and methods}

\subsection{Enzymatic kinetics}

Hyaluronidase from sheep testes (Type II Ref H2126, Sigma), alginate lyase from Pseudoalteromonas alginovora (a gift from CEVA, Centre de Valorisation des Algues, France), pectolyase from Aspergillus japonicus (Sigma P3026) and pectate lyase from Thermotoga maritima (Parisot et al., 2002) (prepared in-lab) were tested respectively on hyaluronic acid from Streptococcus equi sp (Sigma), on alginic acid from Macrocystis pyrifera (Sigma) and on pectin (Sigma) for the two latter enzymes. Substrates at 1 $\mathrm{mg} / \mathrm{mL}$ and enzymes at $5 \mathrm{mg} / \mathrm{mL}$ initial concentration were buffered to $\mathrm{pH} 6$ with $50 \mathrm{mM}$ citrate phosphate buffer except for exopectate lyase from Thermotoga maritima for which $50 \mathrm{mM}$ Tris- $\mathrm{HCl} \mathrm{pH}$ 9 was used. Enzyme dilutions were made in the range of $0.05 \mathrm{mg} / \mathrm{mL}$ to $2 \mathrm{mg} / \mathrm{mL}$ in the appropriate buffer.

$0.8 \mathrm{~mL}$ of enzyme dilution was added to $3.6 \mathrm{~mL}$ of the corresponding substrate. Reactions were carried out for $15 \mathrm{~min}$ at $37^{\circ} \mathrm{C}$ for hyaluronidase and pectolyase, at $30^{\circ} \mathrm{C}$ for alginate lyase and at $80^{\circ} \mathrm{C}$ for exopectate lyase. Substrates alone were incubated at the appropriate temperature prior to the addition of enzyme.

Upon kinetics, samples were heated at $100^{\circ} \mathrm{C}$ for $10 \mathrm{~min}$ and then centrifuged for $7 \mathrm{~min}$ at $10000 \mathrm{~g}$. Supernatants were stored at $-20^{\circ} \mathrm{C}$ until assays.

\subsection{Reducing sugars assay}

Reducing sugars were assayed using the Park method (Park and Johnson, 1949) based on the reduction of ferricyanide ions measured at $690 \mathrm{~nm}$. Briefly, $70 \mu \mathrm{L}$ of sample or standard were mixed with $140 \mu \mathrm{L}$ of reagent AP (potassium hexacyanoferrate $0.5 \mathrm{~g} / \mathrm{L}$; dipotassium hydrogenophosphate 35 $\mathrm{g} / \mathrm{L} \mathrm{pH} \mathrm{10.6)} \mathrm{and} 70 \mu \mathrm{L}$ of reagent BP (sodium carbonate $4.54 \mathrm{~g} / \mathrm{L}$; potassium cyanide $0.65 \mathrm{~g} / \mathrm{L}$ ). The mixture was heated for $7 \mathrm{~min}$ at $100^{\circ} \mathrm{C}$. Then samples were cooled on ice for 4 min and $140 \mu \mathrm{L}$ of reagent $\mathrm{CP}$ (chloride iron (III)- $6 \mathrm{H}_{2} \mathrm{O} 4.164 \mathrm{~g} / \mathrm{L}$; polyvinyle pyrrolidone $20 \mathrm{~g} / \mathrm{L}$, sulfuric acid $1.02 \mathrm{M}$ final concentration) were added and mixed. After $15 \mathrm{~min}$ in the dark, the absorbance was read at $690 \mathrm{~nm}$. The range of reducing sugars (glucose equivalent) detected with this method is 2.5 to $40 \mu \mathrm{g} / \mathrm{mL}$.

The second method used has been described by Myklestad (Myklestad et al., 1997) and is also based on the reduction of ferricyanide ions by reducing sugars. The reduced ferrocyanide subsequently reacts with TPTZ (2,4,6-Tripyridyl-s-triazine) to give a colored complex. $70 \mu \mathrm{L}$ of sample or standard were mixed with $70 \mu \mathrm{L}$ of reagent $\mathrm{AM}$ (sodium hydroxide $400 \mathrm{mg} / \mathrm{L}$; sodium carbonate $20 \mathrm{~g} / \mathrm{L}$; potassium hexacyanoferrate $230 \mathrm{mg} / \mathrm{L}$ ) and then kept for $10 \mathrm{~min}$ at $100^{\circ} \mathrm{C}$. $70 \mu \mathrm{L}$ of reagent $\mathrm{BM}$ (sodium acetate $164 \mathrm{~g} / \mathrm{L}$; citric acid $42 \mathrm{~g} / \mathrm{L}$; acetic acid $300 \mathrm{~g} / \mathrm{L} ; 324 \mathrm{mg} / \mathrm{L}$ of chloride iron(III)- $6 \mathrm{H}_{2} \mathrm{O}$ ) and $140 \mu \mathrm{L}$ of reagent CM (TPTZ $0.78 \mathrm{mg} / \mathrm{mL}$ in $3 \mathrm{M}$ acetic acid) were added immediately and mixed. The absorbance was read at $595 \mathrm{~nm}$ after $30 \mathrm{~min}$. The range of reducing sugars (glucose equivalent) detected with this method is 0.2 to $10 \mu \mathrm{g} / \mathrm{mL}$.

\subsection{Double bond assay}

Depolymerization was detected by the production of double bond by $\beta$-elimination at $232 \mathrm{~nm}$. Samples from pectolyase, exopectate lyase and alginate lyase kinetics were also analyzed by the reading of the absorbance with a spectrophotometer at $37^{\circ} \mathrm{C}, 80^{\circ} \mathrm{C}$ and $30^{\circ} \mathrm{C}$ respectively (Unicam UV/visible spectrophotometer). $800 \mu \mathrm{L}$ of the kinetic samples after the 15 min reaction were taken and absorbance at $232 \mathrm{~nm}$ was read in $10 \mathrm{~mm}$ quartz cells. 


\subsection{High performance size exclusion chromatography}

The system was composed of a PL Aquagel-OH-Mixte $8 \mu \mathrm{m}$ (Varian) guard column ( $\Phi 7.5 \mathrm{~mm} \times \mathrm{L} 50$ $\mathrm{mm}$ ) and a PL Aquagel-OH-Mixte $8 \mu \mathrm{m}$ (Varian) separation column ( $\Phi 7.5 \mathrm{~mm} \times \mathrm{L} 300 \mathrm{~mm}$, operating range : $10^{2}-10^{7} \mathrm{~g} / \mathrm{mol}$ ), a pump and an injector (Kontron Instrument). Elution was performed at 1 $\mathrm{mL} / \mathrm{min}$ with $0.1 \mathrm{M}$ ammonium acetate filtrated on $0.1 \mu \mathrm{m}$ membrane (Durapore Membrane, PVDF, Hydrophilic type VVLP, Millipore). Samples were centrifuged (10000 rpm, $10 \mathrm{~min}$, ambient temperature) and filtrated on $0.45 \mu \mathrm{m}$ cellulose acetate $4 \mathrm{~mm}$ syringe filter prior to injection $(100 \mu \mathrm{L})$. A differential refractive index detector (RI) (Hitachi L2490) and a multi-angle light scattering detector (mini-Dawn $^{\mathrm{TM}}$ Treos $^{\mathrm{TM}}$, Wyatt Technology, Inc) were coupled on-line and the data computed with Astra $^{\mathrm{TM}}$ software for absolute molar mass determinations.

\subsection{Electrophoresis in agarose gel}

$0.7 \%$ agarose gel was prepared in TAE buffer (0.04 M Tris acetate; $0.01 \mathrm{M}$ EDTA, pH 8.5). $30 \mu \mathrm{L}$ of samples in native electrophoresis buffer (Bio-Rad) were loaded and electrophoresis was run in TAE buffer for 2 hours in a Maxi cuve $(20 \mathrm{~cm} \times 10 \mathrm{~cm}$ gel, Fisher Bioblock Scientific). Gels were fixed for 4 hours in $25 \%(\mathrm{v} / \mathrm{v})$ isopropanol and then colored over night by Stains All (1-Ethyl-2-[3-(1ethylnaphtho[1,2-d]thiazolin-2-ylidene)-2-methylpropenyl]naphtho[1,2-d]thiazolium (Sigma)) solution prepared as follows: $5 \mathrm{~mL}$ of a mother $0.001 \%$ Stains All solution in dimethylformamide (w/v); $5 \mathrm{~mL}$ of $300 \mathrm{mM}$ Tris- $\mathrm{HCl} \mathrm{pH} \mathrm{8.8;} 5 \mathrm{~mL}$ of dimethylformamide; $25 \mathrm{~mL}$ of isopropanol; $60 \mathrm{~mL}$ of $\mathrm{H}_{2} \mathrm{O}$ (Lee and Cowman, 1994).

\subsection{Enzymatic units}

Each kinetic and each assay were made in triplicates; average points and standard errors were calculated from these data with SigmaPlot software (version 9.0 SPSS, Erkrath Germany). Units were according to the assay: amount of reducing sugars ( $\mu \mathrm{g}$ glucose equivalent) produced per minute for Myklestad and Park methods, $232 \mathrm{~nm}$ absorbance unit increase per minute for double bonds. Determination of molecular weight by size exclusion chromatography was calculated and given in $\mathrm{g} / \mathrm{mol}$. No units were usable for agarose gel electrophoresis method since no molecular weight markers were available for the different polysaccharide substrates.

Statistical calculations were made using a t-student test for non paired samples. Significance was accorded for $\mathrm{P}<0.05$.

\section{Results}

Various enzymes (endolytic or exolytic enzymes) with unknown degree of purity were tested on their appropriate substrate: hyaluronidase on hyaluronic acid, alginate lyase on alginic acid, pectolyase and exopectate lyase on pectin. Kinetics were then analyzed to measure the depolymerization of the polysaccharide by different methods: reducing sugars assays, molecular weight changes (HPSec, agarose gel electrophoresis) and double bond formation in the case of lyases. The methods were performed after a 15 min incubation and then compared in terms of sensitivity, range of use, easiness of handling and extend of use.

\subsection{Reducing sugars assay}

Depolymerization was checked by measuring the amount of reducing sugars released during the breakdown of polysaccharide. Upon incubation, collected samples were assayed by Park and Myklestad methods. The assay of reducing sugars on polysaccharides alone in solution gave a background more or less important depending on the polysaccharide. In the incubation conditions we measured $1.5 \mu \mathrm{g} / \mathrm{mL}$ of reducing sugars for hyaluronic acid and alginic acid alone and $15 \mu \mathrm{g} / \mathrm{mL}$ for pectin. As for native polysaccharide, enzyme in buffer gave also a background level which depends consequently on its concentration used. These values were subtracted from the amount of reducing sugars measured in kinetics samples to get the real amount coming from depolymerization.

Figure 1 shows the amount of reducing sugars released after $15 \mathrm{~min}$ by the different enzymes on their respective polysaccharide as a function of enzyme concentration. Low concentrations of hyaluronidase $(0.05 \mathrm{mg} / \mathrm{mL})$ and alginate lyase $(0.05 \mathrm{mg} / \mathrm{mL})$ gave reducing sugars detected 
significantly only by the Myklestad method. With higher enzyme concentrations, $0.25 \mathrm{mg} / \mathrm{mL}$ of hyaluronidase and $0.5 \mathrm{mg} / \mathrm{mL}$ of alginate lyase, reducing sugars were measured by the Park method. For pectolyase and exopectate lyase kinetics, reaction products must be 5 times diluted prior to the Park assay for the whole range of enzyme concentrations, because native pectin is rich in reducing sugars. Detection of depolymerization with Myklestad method was possible in our experiments from $0.2 \mu \mathrm{g} / \mathrm{mL}$ of reducing ends and with Park method from $1.9 \mu \mathrm{g} / \mathrm{mL}$ suggesting that Myklestad method is ten times more sensitive than Park method. But Myklestad assay is very sensitive to interfering compounds and is therefore not usable with all enzymes or polysaccharides.

\subsection{Double bond detection}

Double bonds appearing on the degradation products and resulting from the $\beta$-elimination due to lyase were measured by absorbance at $232 \mathrm{~nm}$. Figure 2 gives the results obtained for the three lyases tested. This double bond assay is directly linked to reducing sugars results since both assays have been performed on the same samples from the same kinetics. As for reducing sugars assay, the background due to polysaccharide and enzyme in solution was removed from the value measured to get the increase in absorbance. With alginate lyase on alginic acid, depolymerization was not detectable at the lowest enzyme concentrations but only from $0.25 \mathrm{mg} / \mathrm{mL}$ of enzyme. For the kinetics on pectin with pectolyase and exopectate lyase, depolymerizations were quantifiable from $0.05 \mathrm{mg} / \mathrm{mL}$ of enzymes. But the enzyme alone causing interferences with the assay (the value of the absorbance at $232 \mathrm{~nm}$ for exopectate lyase at $0.25 \mathrm{mg} / \mathrm{mL}$ is 1.74), the saturation of the measurement was reached with the addition of enzyme and consequently, the increase in absorbance due to depolymerization could not be measured. Thus, above the concentrations of $0.05 \mathrm{mg} / \mathrm{mL}$ of exopectate lyase and $0.5 \mathrm{mg} / \mathrm{mL}$ of pectolyase, the depolymerization was not assessable with this method. The high UV absorbance is probably due to the mixture of components in enzyme preparation (the mixture of enzymes but also of additives such as maceration stimulating factors).

\subsection{High Performance Size Exclusion Chromatography (HPSec)}

Polysaccharide molecular weight was measured using size exclusion chromatography. In figure 3 , an example of the obtained chromatograms for hyaluronic acid submitted to different concentrations of hyaluronidase is shown. With the $10^{2}-10^{7} \mathrm{~g} / \mathrm{mol}$ operating range column, depolymerization was detected and quantifiable for the whole range of hyaluronidase concentrations, and gave degradation products with molecular weights between 576000 and $19000 \mathrm{~g} / \mathrm{mol}$.

The decrease of polysaccharide molecular weight catalyzed by all tested enzymes is given in figure 4 . By this method, depolymerization was detected from the lowest enzyme concentration $(0.05 \mathrm{mg} / \mathrm{mL})$ in all cases but can not be systematically followed for the whole range of enzyme concentrations. With pectin, which has a low initial molecular weight $(100000 \mathrm{~g} / \mathrm{mol})$ compared to hyaluronic acid $(576000$ $\mathrm{g} / \mathrm{mol}$ ) and alginic acid $(196000 \mathrm{~g} / \mathrm{mol})$, depolymerization with pectolyase was quantifiable up to the enzyme concentration $0.5 \mathrm{mg} / \mathrm{mL}$ and gave degradation products of about $10000 \mathrm{~g} / \mathrm{mol}$. Above this pectolyase concentration, hydrolysates became too small to be detected and thus would require a column with an appropriate resolution for oligosaccharides. With exopectate lyase, as expected for an exo-enzyme, the decrease in molecular weight was low since we found degradation products with molecular weight quite similar for enzyme concentrations ranging between 0.25 and $1 \mathrm{mg} / \mathrm{mL}$.

\subsection{Electrophoresis of polysaccharide}

Samples withdrawn upon kinetics described above were analyzed by agarose gel electrophoresis and stained by "Stains All" suitable for acidic polysaccharides such as pectin, alginic acid and hyaluronic acid which all contain uronic acids. Figure 5 shows the agarose gels $(0.7 \%)$ representing the migration distance of hyaluronic acid and alginic acid products after a 15 min reaction with different enzyme concentrations. Native polysaccharides do not migrate in the same manner but depolymerization was visible from the lowest enzyme concentrations (i.e. $0.05 \mathrm{mg} / \mathrm{mL}$ for hyaluronidase and alginate lyase). With pectin, the decrease of molecular weight was visible from 0.05 $\mathrm{mg} / \mathrm{mL}$ of pectolyase but with the exopectate lyase, depolymerization was not clearly detected since the exo-enzyme caused low decrease of molecular weight (data not shown). Upon depolymerization low molecular weight degradation products rapidly reached the maximum of migration with enzyme concentrations of $0.5 \mathrm{mg} / \mathrm{mL}$ for hyaluronidase, $1 \mathrm{mg} / \mathrm{mL}$ for alginate lyase, and $0.05 \mathrm{mg} / \mathrm{mL}$ for pectolyase. At these stages, electrophoresis allows detection but not a quantification of the depolymerization. The experiment allowed us to get a resolution in the migration above $40000 \mathrm{~g} / \mathrm{mol}$, 
making the method more usable to follow narrow depolymerization and relevant to polysaccharide displaying molecular weight higher than $100000 \mathrm{~g} / \mathrm{mol}$.

\section{Discussion}

In the aim to find enzymes or microorganisms able to depolymerize a given polysaccharide, we assessed known methods for the detection of the depolymerization. To obtain various conditions of reaction, we tested several enzymes and substrates and analyzed the sensitivity, as well as the range of use of the methods upon the different kinetics. For each enzyme/polysaccharide couple tested, methods were compared as a function of enzyme concentration. Results are given in figure 6 .

Reducing sugars assays are routinely used to detect enzymatic depolymerization. Among these assays, Park and Myklestad methods are known to be sensitive, compared to dinitrosalicylic acid method (Miller, 1959) or Somogy-Nelson method (Nelson, 1977) (about 10 times less sensitive). Moreover, they can be used with a wide range of polysaccharides contrary to Morgan-Elson method (Reissig et al., 1955) for example which can only detect $\mathrm{N}$-acetyl reducing sugars. As expected we found a great sensitivity for Myklestad method with detection from the lower enzyme concentrations used in our assay (corresponding to low level of depolymerization). Sensitivity is lower for Park method, but contrary to Myklestad method which is very sensitive to interfering compounds the method was usable with all kind of polysaccharide/enzyme couples tested. When polysaccharides display high content of reducing sugars (as pectin), dilution is required to measure the depolymerization using cited assays. This dilution can be a trouble when depolymerization is limited because the amount of reducing sugars is also diluted and thus can become too low to be detected by the assay. Another limit for these assays is the reaction with interfering compounds, especially when activity of whole microorganisms are tested in classical microbiological media (and particularly rich media) because they contain high amounts of reducing compounds which interfere with the assays. When possible, specific media with a non-reducing carbon source (Meeuwsen et al., 2000) have to be used. This trouble can also be avoided by diluting the sample to decrease the level of interferences but, as described before, it can result in a loss of detection of the depolymerization (for example, Park method assaying reducing ends on a LB sample gives an amount in reducing ends more than $50 \mu \mathrm{g} / \mathrm{mL}$ and a 10 times dilution is required to decrease the amount to $15 \mu \mathrm{g} / \mathrm{mL}$ to be in the range of detection).

To study the breakdown of polysaccharide by lyases, the absorbance at $232 \mathrm{~nm}$ is usually monitored. Alternatively, thiobarbituric acid can also be used in the TBA assay (Nedjma et al., 2001) but this latter is less sensitive as we found ourselves for alginate lyase (data not shown). The absorbance at $232 \mathrm{~nm}$ takes advantage of directly and continuously assaying the depolymerization upon the kinetics. Although this method is as sensitive as Park method (and less sensitive than Myklestad method), it is easily biased by interfering compounds and thus becomes difficult to use with crude enzymatic extracts or culture media.

In the monitoring of polysaccharide degradation, high performance size exclusion chromatography is rather used to get quantitative data of a known depolymerization (Roubroeks et al., 2000) than to support screening experiments because it requires specific equipment and time to process samples. In our work, HPSec is the most sensitive method among those tested and is also appropriate upon a wide range of enzyme activity level since the range of resolution of the column was high. Moreover, size exclusion chromatography may be used with pure enzymes as well as with cell extracts from microorganisms, in any kind of media, and with all kind of polysaccharides with little interference with the assay. However, for depolymerization by exo-enzymes yielding a very low decrease in molecular weight, the monitoring may be less appropriate by this method.

Agarose gel electrophoresis is rarely used to follow enzymatic depolymerization and was mostly employed to compare high molecular weight hyaluronan (higher than $300000 \mathrm{~g} / \mathrm{mol}$ ) (Jing et al., 2006). As HPSec analysis, this method displays some advantages including a great sensitivity by detecting the lower levels of depolymerization, the possible use in complex reaction media and for different kinds of enzymes. Although it is restricted to charged polysaccharides, polyanionic polysaccharides are widely distributed in nature: bacterial exopolysaccharides (Sutherland, 1995), glycosaminoglycans and other polysaccharides currently used in industry (pectin, alginate, gellan...). In our experiments, the lower limit in molecular weight resolution was evaluated to be at about $4.10^{4}$ $\mathrm{g} / \mathrm{mol}$, even at higher agarose concentrations (data not shown) ; this excludes analysis of low molecular weight polysaccharides. Moreover, this method is not adapted to follow a low decrease in molecular weight resulting from an exo-enzyme and tends to be rather qualitative than quantitative 
providing a simple "Yes or No" response. Activity can not be evaluated without any molecular weight standards. These latter have to be produced for each new polysaccharide structure since migration depends upon charge as well as molecular size.

In conclusion, we found that HPSec analysis is a very sensitive and universal method for polysaccharide depolymerization evaluation. However, the method is time-consuming, low-throughput and requires specific equipment. By contrast, if the polysaccharide is charged, analysis by electrophoresis on agarose gel is easier to handle, quite high-throughput and is more adapted than reducing sugars assays to screen crude extracts from microorganisms. Otherwise, if the polysaccharide is not charged, reducing sugars assay may be the more appropriate method to detect depolymerization.

\section{References}

Campbell, K.P., D.H. MacLennan, and A.O. Jorgensen (1983). Staining of the Ca2+-binding proteins, calsequestrin, calmodulin, troponin $\mathrm{C}$, and S-100, with the cationic carbocyanine dye "Stains-all". Journal of Biological Chemistry, 258(18), 11267-11273.

Colliec Jouault, S., L. Chevolot, D. Helley, J. Ratiskol, A. Bros, C. Sinquin, O. Roger, and A.M. Fischer (2001). Characterization, chemical modifications and in vitro anticoagulant properties of an exopolysaccharide produced by Alteromonas infernus. Biochimica et Biophysica Acta, 1528(2-3), 141151.

Colliec-Jouault, S., P. Zanchetta, D. Helley, J. Ratiskol, C. Sinquin, A.M. Fischer, and J. Guezennec (2004). Les polysaccharides microbiens d'origine marine et leur potentiel en therapeutique humaine. Pathologie Biologie, 52(3), 127-130.

Gómez Ramírez, M., L.I. Rojas Avelizapa, N.G. Rojas Avelizapa, and R. Cruz Camarillo (2004). Colloidal chitin stained with Remazol Brilliant Blue $R \otimes$, a useful substrate to select chitinolytic microorganisms and to evaluate chitinases. Journal of Microbiological Methods, 56(2), 213-219.

Guezennec, J., P. Pignet, Y. Lijour, E. Gentric, J. Ratiskol, and S. Colliec-Jouault (1998). Sulfation and depolymerization of a bacterial exopolysaccharide of hydrothermal origin. Carbohydrate Polymers, 37(1), 19-24.

Jing, W., F. Michael Haller, A. Almond, and P.L. DeAngelis (2006). Defined megadalton hyaluronan polymer standards. Analytical Biochemistry, 355(2), 183-188.

Kühn, A.V., J.-H. Ozegowski, G. Peschel, and R.H.H. Neubert (2004). Complementary exploration of the action pattern of hyaluronate lyase from Streptococcus agalactiae using capillary electrophoresis, gel-permeation chromatography and viscosimetric measurements. Carbohydrate Research, 339(15), 2541-2547.

Lee, H.G. and M.K. Cowman (1994). An agarose-gel electrophoretic method for analysis of hyaluronan molecular-weight distribution. Analytical Biochemistry, 219(2), 278-287.

Meeuwsen, P.J.A., J.-P. Vincken, G. Beldman, and A.G.J. Voragen (2000). A universal assay for screening expression libraries for carbohydrases. Journal of Bioscience and Bioengineering, 89(1), 107-109.

Miller, G.L. (1959). Use of dinitrosalicylic acid reagent for determination of reducing sugar. Analytical Chemistry, 31(3), 426-428.

Myklestad, S.M., E. Skånøy, and S. Hestmann (1997). A sensitive and rapid method for analysis of dissolved mono- and polysaccharides in seawater. Marine Chemistry, 56(3-4), 279-286.

Nardella, A., F. Chaubet, C. Boisson-Vidal, C. Blondin, P. Durand, and J. Jozefonvicz (1996). Anticoagulant low molecular weight fucans produced by radical process and ion exchange chromatography of high molecular weight fucans extracted from the brown seaweed Ascophyllum nodosum. Carbohydrate Research, 289, 201-208.

Nedjma, M., N. Hoffmann, and A. Belarbi (2001). Selective and sensitive detection of pectin lyase activity using a colorimetric test: application to the screening of microorganisms possessing pectin lyase activity. Analytical Biochemistry, 291(2), 290-296.

Nelson, N. (1977). Citation classics - Photometric adaptation of Somogyi method for determination of glucose. Current Contents (3), 13-13.

Ofman, D., G.C. Slim, D.K. Watt, and S.C. Yorke (1997). Free radical induced oxidative depolymerisation of chondroitin sulphate and dermatan sulphate. Carbohydrate Polymers, 33(1), 4756 . 
Parisot, J., A. Ghochikyan, V. Langlois, V. Sakanyan, and C. Rabiller (2002). Exopolygalacturonate lyase from Thermotoga maritima: cloning, characterization and organic synthesis application. Carbohydrate Research, 337(16), 1427-1433.

Park, J.T. and M.J. Johnson (1949). A submicrodetermination of glucose. Journal of Biological Chemistry, 181(1), 149-151.

Pettersson, B. and K.-E.L. Eriksson (2000). A standardized spectrophotometric assay of endoglycanase activities using dyed, amorphous polysaccharides. Analytical Biochemistry, 285(2), 220-224.

Reissig, J.L., J.L. Storminger, and L.F. Leloir (1955). A modified colorimetric method for the estimation of N-acetylamino sugars. Journal of Biological Chemistry, 217(2), 959-66.

Roubroeks, J.P., G. Skjak-Braek, L. Ryan, and B.E. Christensen (2000). Molecular weight dependency on the production of the TNF stimulated by fractions of rye $(1 \rightarrow 3),(1 \rightarrow 4)-\beta$-d-Glucan. Scandinavian Journal of Immunology, 52(6), 584-587.

Ruijssenaars, H.J. and S. Hartmans (2001). Plate screening methods for the detection of polysaccharase-producing microorganisms. Applied Microbiology and Biotechnology, 55, 143-149.

Samama, M. M. and P. C. Desnoyers (1997). Low-molecular-weight heparins : biochemistry and pharmacoloy. In A.A. Sasahara, \& J. Loscalzo. New therapeutic agents in thrombosis and thrombolysis (pp. 87-101). New York, Marcel Dekker, Inc.

Shively, J.E. and H.E. Conrad (1976). Formation of anhydrosugars in the chemical depolymerization of heparin. Biochemistry, 15(18), 3932-3942.

Sutherland, I.W. (1995). Polysaccharide lyases. FEMS Microbiology Reviews, 16(4), 323-347.

Ten, L.N., W.-T. Im, M.-K. Kim, M.S. Kang, and S.-T. Lee (2004). Development of a plate technique for screening of polysaccharide-degrading microorganisms by using a mixture of insoluble chromogenic substrates. Journal of Microbiological Methods, 56(3), 375-382.

Volpi, N. and F. Maccari (2006). Electrophoretic approaches to the analysis of complex polysaccharides. Journal of Chromatography B, 834(1-2), 1-13.

Weitz, J. I. and J. Hirsh (1997). Overview of new developments in heparins, thrombin inhibitors, and other new and novel agents. In A.A. Sasahara, \& J. Loscalzo. New therapeutic agents in thrombosis and thrombolysis (pp. 77-86). New York, Marcel Dekker, Inc.

Wood, P.J., J.D. Erfle, and R.M. Teather (1988). Use of complex formation between Congo Red and Polysaccharides in detection and assay of polysaccharides hydrolases. Methods in Enzymology, 160, 59-74.

Zanchetta, P., N. Lagarde, and J. Guezennec (2003). A new bone-healing material: A hyaluronic acidlike bacterial exopolysaccharide. Calcified Tissue International, 72(1), 74-79. 


\section{Figures}

Figure 1

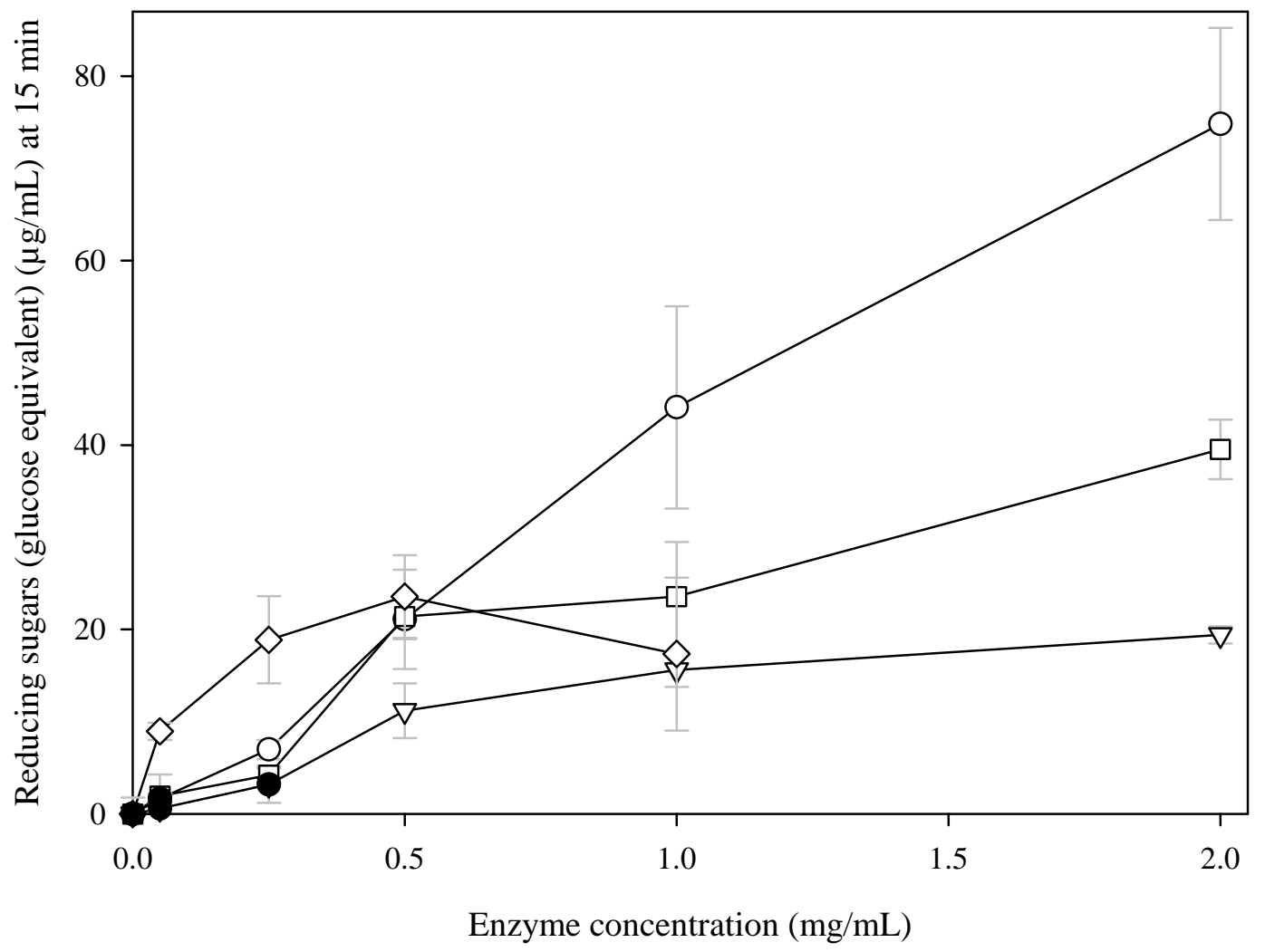

Figure 1: Amount of reducing sugars $(\mu \mathrm{g} / \mathrm{mL}$ ) assayed by Park method (opened symbols) or Myklestad method (closed symbols) as a function of enzyme concentration. Hyaluronidase on hyaluronic acid (O); alginate lyase on acid alginic $(\nabla)$; pectolyase on pectin $(\square)$ and exopectate lyase on pectin $(\diamond)$. Symbols give the average point of the experimental data obtained in triplicates with error bars representing standard errors. 
Figure 2

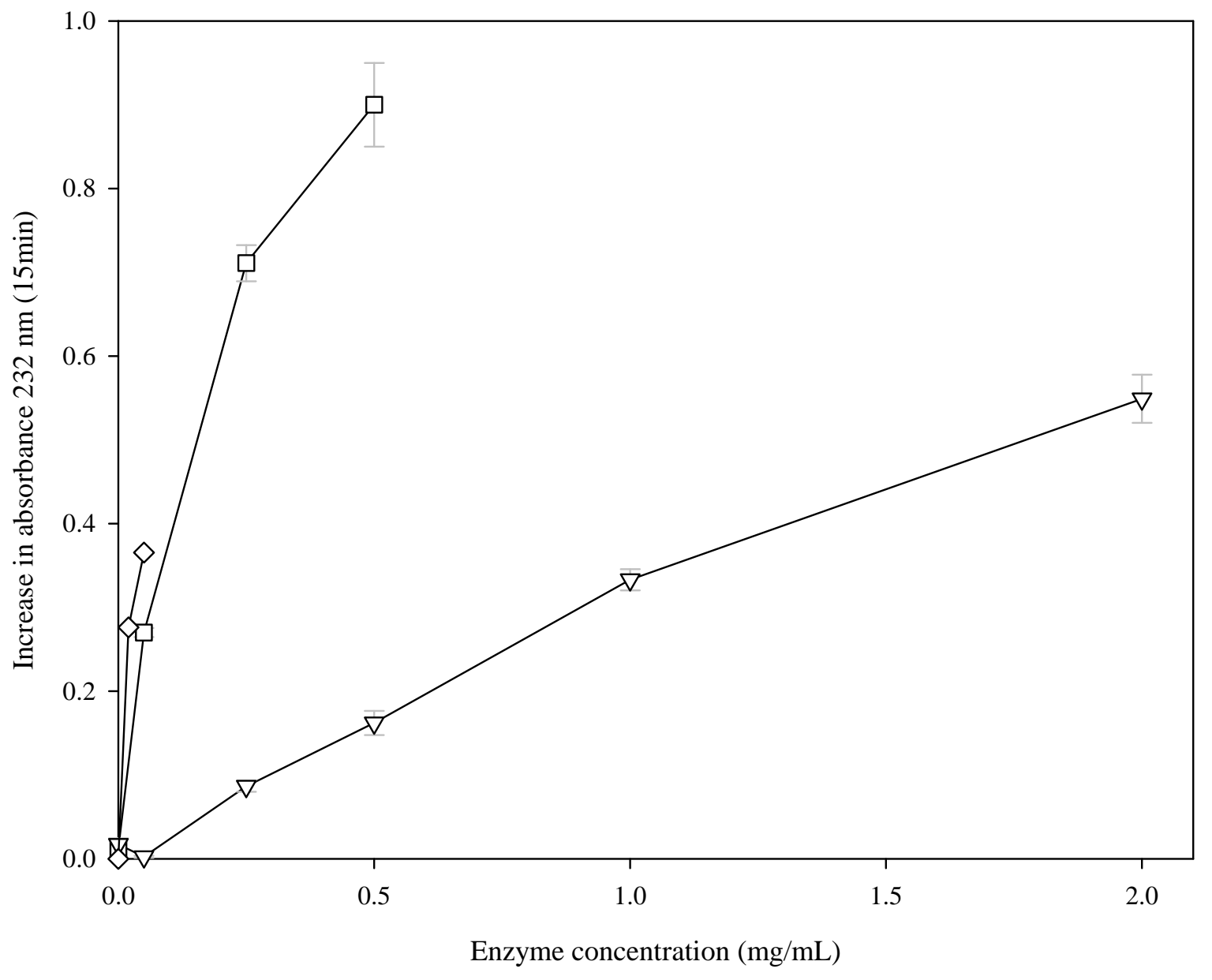

Figure 2: Absorbance at $232 \mathrm{~nm}$ measured after $15 \mathrm{~min}$ for alginate lyase on alginic acid $(\nabla)$; pectolyase $(\square)$ and exopectate lyase $(\diamond)$ on pectin as a function of enzyme concentration. Symbols give the average point of the experimental data obtained in triplicates with error bars representing standard errors. 
Figure 3

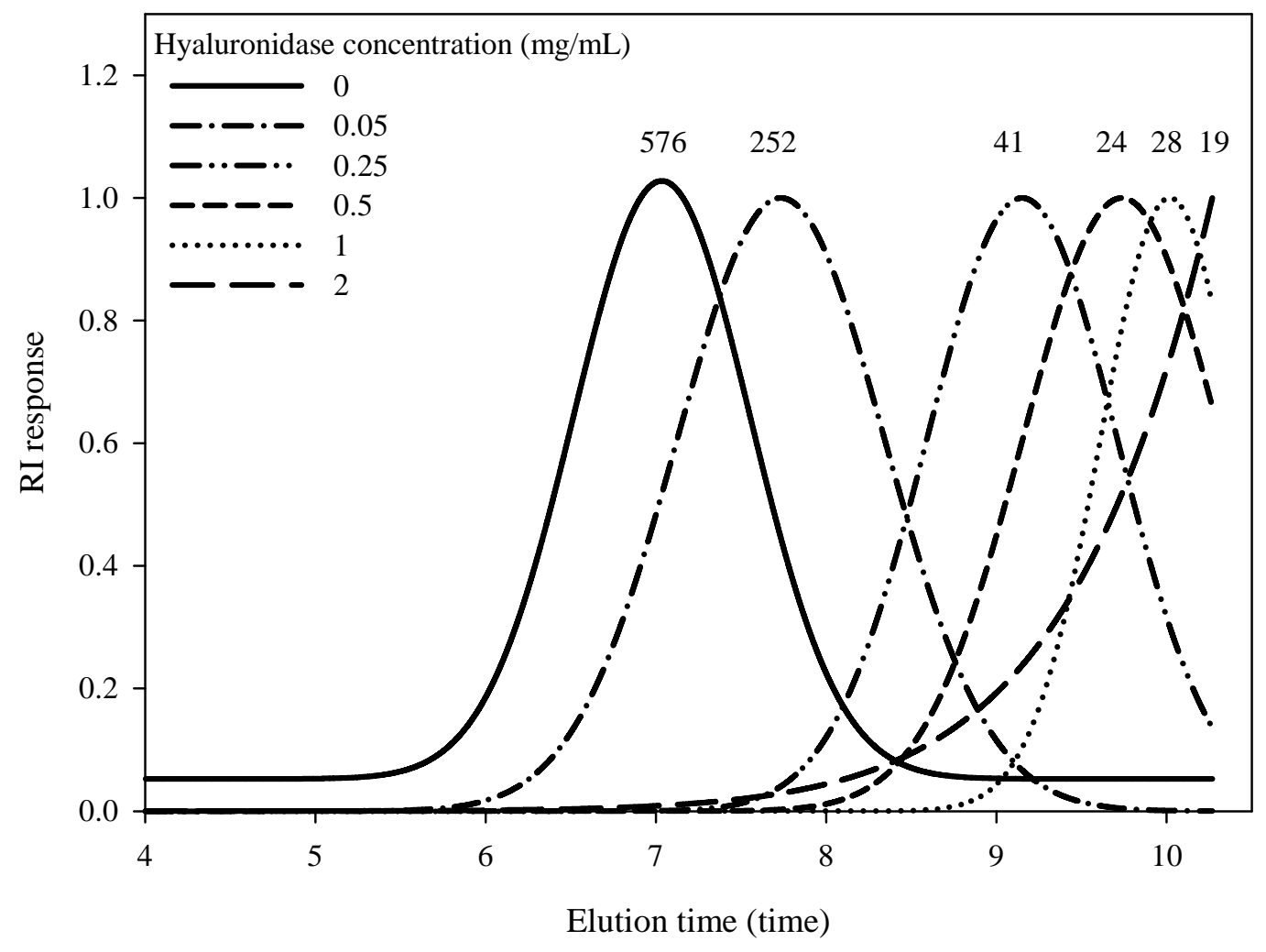

Figure 3: Elution profile (Refractive Index, RI) of hydrolysed hyaluronic acid upon different concentrations of hyaluronidase $(0-2 \mathrm{mg} / \mathrm{mL})$ obtained from HPSec. Molecular weights were calculated by Astra software from light scattering detector and RI detector signals. Average molecular weights measured for each elution profile are given above the elution peak (in $10^{-3} \mathrm{~g} / \mathrm{mol}$ ). 
Figure 4

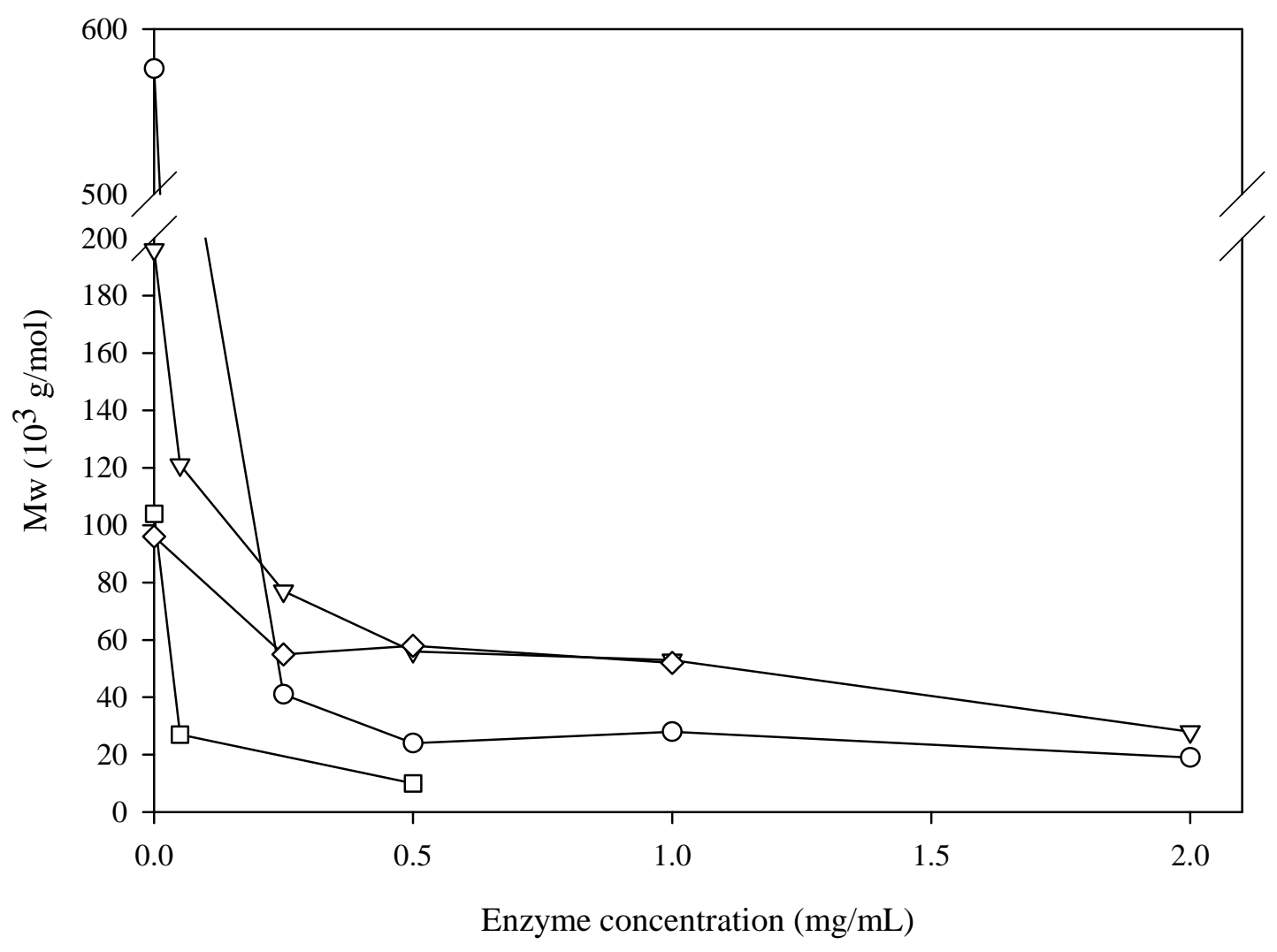

Figure 4: Polysaccharide molecular weight after 15 min measured by HPSec upon kinetics with hyaluronidase $(\bigcirc)$; alginate lyase $(\nabla)$; pectolyase $(\square)$ and exopectate lyase $(\diamond)$ as a function of enzyme concentration. 
Figure 5

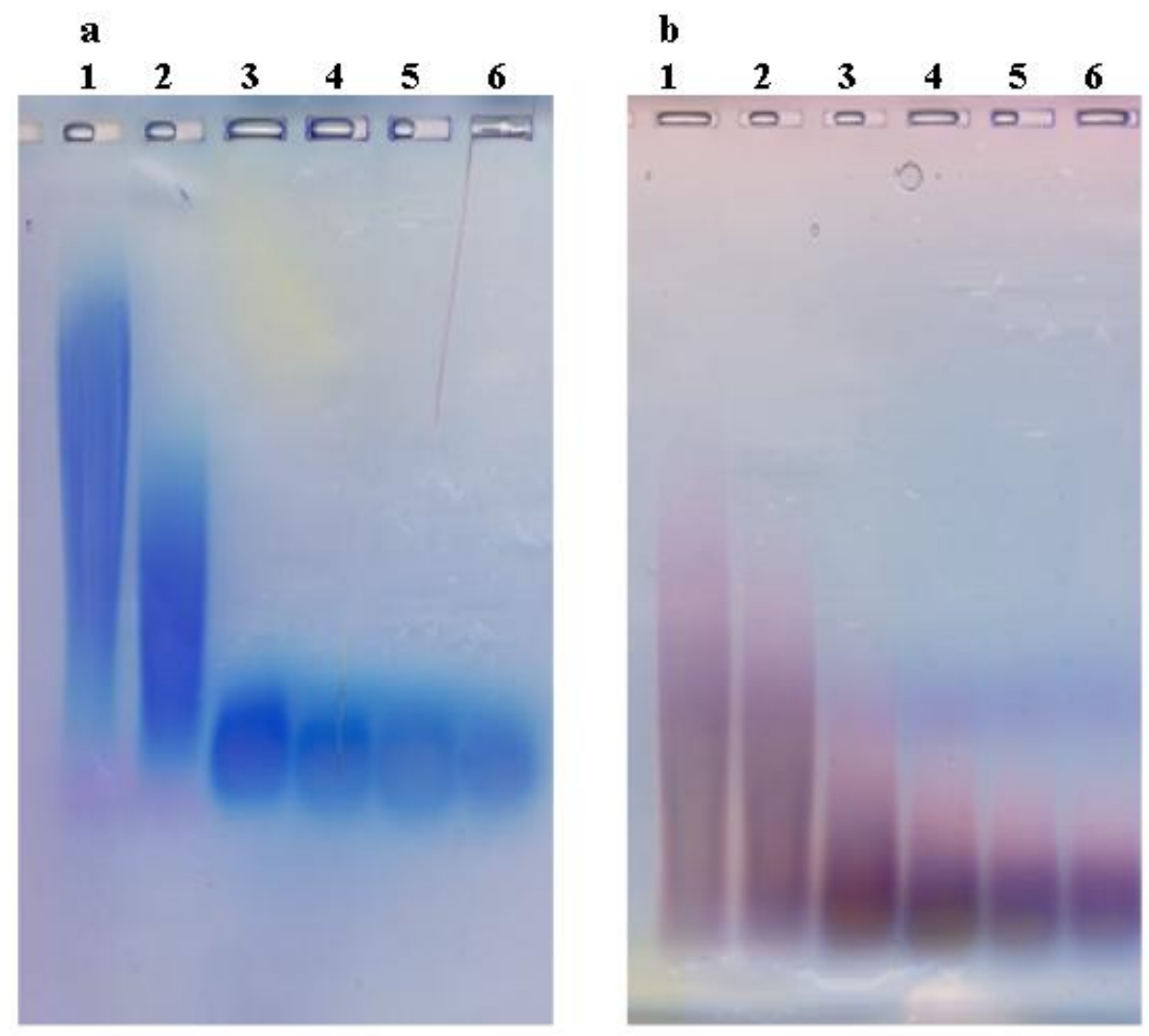

Figure 5: Electrophoretic migration of hyaluronic acid (a) and alginic acid (b), upon incubation with hyaluronidase and alginate lyase, respectively. Gel was $0.7 \%$ agarose in TAE buffer. $30 \mu \mathrm{L}$ of the kinetic samples withdrawn at 15 min were loaded and allowed to migrate during two hours before Stains all coloration of the gel. Enzyme concentrations are (mg/ml): 0 (lane 1), 0.05 (lane2), 0.25 (lane3), 0.5 (lane 4), 1 (lane 5), 2 (lane 6). 
Figure 6

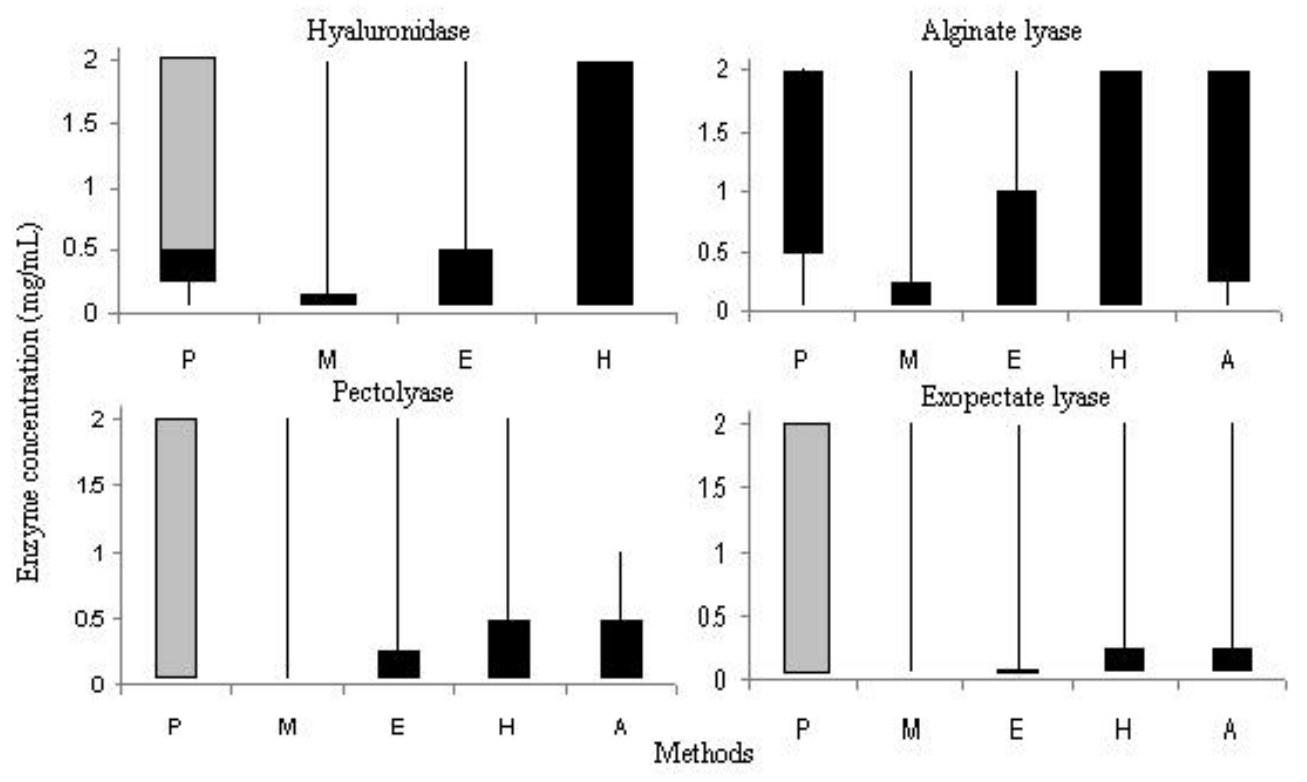

Figure 6: Sensitivity and range of detection of the different methods tested (Park method $(P)$, myklestad method $(M)$, electrophoresis in agarose $(E)$, HPsec $(H)$, Absorbance at 232nm $(A)$ ) using enzyme concentration, upon each enzyme/polysaccharide couples. Black lines give the range of enzyme concentrations tested, black boxes the range of enzyme concentrations allowing detection and gray boxes the range of enzyme concentrations needing sample dilutions before assay. 